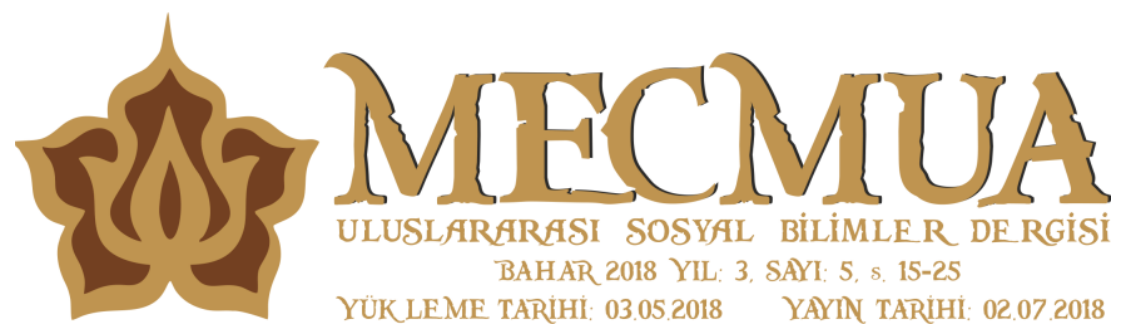

Mehmet Murat PAYAM"

\title{
GÜVENLİK BAĞLAMINDA GÜÇ KULLANIMI VE ALGI(LAMA) YÖNETIMI
}

\begin{abstract}
Öz
Günümüzde tüm insanların ve devletlerin en öncelikli sorunu haline gelen güvenlik, herkesin hayatında büyük bir yer kaplamaktadır. Bu yüzden farklı disiplinlerden birçok araştırmacı, güvenlik konusu üzerine yoğunlaşmış, insanların ve devletlerin güvenliğini etkin bir şekilde sağlamanın yollarını bulmaya çalışmışlardır. Devletler bir yandan kendi çıkarlarını en üst seviyeye çıkarmak, bölgesel ve küresel bir güç olmak, diğer yandan kendisinin ve vatandaşlarının güvenliğini sağlamak için çok çeşitli araç ve yöntemler kullanırlar. Devletlerin kullandığı bu araçlardan birisi güçtür. Bu bağlamda, başlangıçta güvenliği sağlamaya yönelik ana strateji olarak devletler tarafından uzun süre sert güç kullanılmış ve fakat sadece sert gücün güvenliği sağlamada etkisiz olduğu saptanmıştır. Ardından devletler, kendilerinin ve vatandaşlarının güvenliği için sert güçle birlikte veya sert güce alternatif bir yaklaşım olarak yumuşak gücü kullanmaya başlamışlardır. Güvenlik problemlerinin çözümünde sadece yumuşak güç kullanımının bir noktaya kadar etkili olduğu görülmüş fakat istenen netice elde edilememiştir. Buna ilaveten, güvenlik risk ve tehditlerinin küresel ve bölgesel ölçekte artması, araştırmacıları gerçekten karmaşık olan modern güvenlik sorunsalıyla ilgilenmede daha stratejik yöntemleri aramaya sevk etmiştir. Bunun sonucunda, sert ve yumuşak gücün negatif yönlerini elimine edip pozitif yönlerini kendi içerisinde birleştiren "akıllı güç" adında yeni bir yaklaşım ortaya konmuştur. Sert, yumuşak ve akıllı güç tartışmasında, bazı yazarlar algı yönetimini bir "akıllı güç" aracı olarak değerlendirirler. Devletlerin kendi çıkarları için uluslararası düzlemde alg1 yönetimini kullanmaları ise genelde "kamu diplomasisi" olarak adlandırılmaktadır. Bu açıdan günümüzde çeşitli düzeyde güç kullanan devletlerin ulusal düzlemde en etkin ve sessiz silahı algıları yönetmek, uluslararası düzlemde ise kamu diplomasisidir denilebilir. Bu bağlamda bu makalede, algı yönetimi ve çeşitli güç kullanımı güvenlik açısından çeşitli boyutlarıyla ele alınmış ve uygulanabilir öneriler sunulmuştur.
\end{abstract}

Anahtar Kelimeler: Güvenlik, Sert Güç, Yumuşak Güç, Akıllı Güç, Alg1 Yönetimi

\section{PERCEPTION MANAGEMENT AND USE OF POWER IN CONTEXT OF SECURITY}

\begin{abstract}
Security, which has become a top priority for all people and governments today, takes a great place in everyone's life. Therefore, many researchers from different disciplines have concentrated on the issue of security and have sought to find ways to effectively ensure the security of people and states. In this regard, states use a variety of tools and
\end{abstract}

Dr. Öğr. Üyesi, Adıyaman Üniversitesi, Sosyal Bilimler Meslek Yüksekokulu, Mülkiyet Koruma ve Güvenlik Bölümü, mpayam@adiyaman.edu.tr 
methods to maximize their own interests, to become a regional and global power, and to secure their own and their citizens. One of the methods used by the states is power. In this context, initially the states have used hard power for a long time as the main strategy for ensuring the security, but it has been determined that use of hard power only for ensuring security is ineffective. The states have then begun to use soft power with hard power or as an alternative approach to hard power for the security of their own and their citizens. It has been found that the use of soft power only is effective to some extent in solving security problems, but the desired result is not achieved. In addition, the increase in security risks and threats at the global and regional scale has led researchers to look for more strategic ways to deal with modern security problems that are really complex. As a result, a new approach called "smart power", which eliminates the negative aspects of hard and soft power and incorporates their positive aspects into itself, has been put forward. In the discussion of hard, soft and smart power, some writers regard perception management as a "smart power" tool. It is generally called "public diplomacy" when governments use perception management at the international level for their own interests. In this respect, it can be said that the states that use force at various levels today manage the most effective and silent weapons as perception management at the national level and public diplomacy at the international level. In this context, in this article, perception management and various uses of power are discussed in different dimensions in terms of security and finally some applicable proposals are presented.

Keywords: Security, Hard Power, Soft Power, Smart Power, Perception Management

\section{Giriş}

Günümüzde tüm insanların ve devletlerin en öncelikli sorunu haline gelen güvenlik, herkesin hayatında büyük bir yer kaplamaktadır. Güvenlik, toplum yaşamında yasal düzenin aksamadan yürütülmesi, kişilerin korkusuzca yaşayabilmesi durumudur (TDK, 2018). İnsanlardaki güvenlik algısı, nesnel ve öznel nitelik taşıdığından, güvenlik problemlerinin çözümünde güç kullanımı ve kullanılan gücün meşruiyeti yönünden ise alg1 yönetiminin önemli bir rol oynadığ 1 tartışma götürmez bir gerçektir. Bu yüzden farklı disiplinlerden birçok araştırmacı, güvenlik konusu üzerine yoğunlaşmış ve insanların ve devletlerin güvenliğini etkin bir şekilde sağlamanın ve bunu sağlarken de kullanılan gücün meşrulaştırılması yollarını bulmaya çalışmışlardır.

Devletler bir yandan kendi çıkarlarını en üst seviyeye çıkarmak, bölgesel ve küresel bir güç olmak, diğer yandan kendisinin ve vatandaşlarının güvenliğini sağlamak için çok çeşitli araç ve yöntemler kullanırlar. Bu yöntemlere diplomasi ve diplomatik yöntemler, propaganda, ekonomik araçlar, iç işlerine karışma, güç kullanma tehdidinde bulunma veya silahlı güç kullanımı (Arı, 1997) örnek olarak verilebilir. Güç, devletlerin kullanageldiği ve kısa vadede yarar sağladığına inanılan bu araçlardan birisidir. Sözlükte güç, "düşünce ve ahlak yönünden bir etki yapabilme veya bir etkiye direnebilme yeteneği" (TDK, 2018) olarak tanımlanmaktadır. Yani en genel anlamıyla güç, aktörlerin istediklerini elde etmek için diğerlerini etkileme kabiliyeti veya istenilen bir etkiye direnebilme yeteneğidir. Başka bir anlatımla güç, istenen bir sonuç elde etmek için diğerlerinin davranışlarını etkileme becerisidir, baskı ve tehditle, teşvik ve ödemeler teklif ederek ve istediğiniz şeyi başkalarının istemesini sağlayarak temelde üç şekilde kullanılabilir (Nye, 2004).

Özellikle devletler tarafindan istendik politik amaçlara ulaşmak için araç olarak kullanılan gücün literatürde, kullanım şekilleri de göz önüne alınarak, "sert güç̧", 
"yumuşak güç" ve "akıllı güç" gibi bazı sınıflandırmalara tabii tutulduğu görülmektedir. Sert güç, teşviklere veya tehditlere dayanırken yumuşak güç başkalarının tercihlerini şekillendirme becerisine dayanmaktadır (Nye, 2004). Akıllı güç ise, sert güç ve yumuşak gücün etkin bir şekilde beraber kullanımını içerir. Devletler tarafından başlangıçta güvenliği sağlamaya yönelik ana strateji olarak uzun süre sert güç kullanılmış ve fakat sadece sert gücün güvenliği sağlamada etkisiz olduğu saptanmıştır. Ardından devletler, kendilerinin ve vatandaşlarının güvenliği için sert güçle birlikte veya sert güce alternatif bir yaklaşım olarak yumuşak gücü kullanmaya başlamışlardır. Güvenlik problemlerinin çözümünde sadece yumuşak güç kullanımının bir noktaya kadar etkili olduğu görülmüş fakat istenen netice elde edilememiştir. Buna ilaveten, güvenlik risk ve tehditlerinin küresel ve bölgesel ölçekte artması, araştırmacıları gerçekten karmaşık olan modern güvenlik sorunsalıyla ilgilenmede daha stratejik yöntemleri aramaya sevk etmiştir. Bunun sonucunda, sert ve yumuşak gücün negatif yönlerini elimine edip pozitif yönlerini kendi içerisinde birleştiren "akıllı güç" adında yeni bir yaklaşım ortaya konmuştur.

Sert, yumuşak ve akıllı güç tartışmasında ise bazı yazarlar, algı yönetimini bir "akıllı güç" aracı olarak değerlendirirler. Örneğin Varoğlu (2013), alg1 yönetimini yumuşak-sert güç ayrımı dışında "akıllı güç" olarak tanımlar. Diğer yandan, devletlerin kendi çıkarları için uluslararası düzlemde alg1 yönetimini kullanmaları ise genelde "kamu diplomasisi" olarak adlandırılmaktadır (Tunç ve Atılgan, 2017). Çeşitli düzeyde güç kullanan devletler, iktidarlarının ve politikalarının meşruiyetini sağlamak için hedef kitlelerin algılamalarını değiştirerek ve hangi algının yerleşmesi isteniyorsa hedef kitleye o algının kazandırılma yöntemlerini uygulayarak ikna etmenin ve onlara kendi gözlerinden dünyaya bakmalarını sağlamanın yollarını ararlar (Akay, 2014). Bu açıdan bakıldığında, günümüzde çeşitli düzeyde güç kullanan devletlerin ulusal düzlemde en etkin ve sessiz silahı algılar1 yönetmek, uluslararası düzlemde ise kamu diplomasisidir denilebilir. Bu bağlamda bu makalede, algı yönetimi ve çeşitli güç kullanımı güvenlik açısından çeşitli boyutlarıyla ele alınmıştır.

\section{Sert Güç}

Herhangi bir ülkenin gücü; diplomatik güç, ekonomik güç, askeri güç ve bilgi gücü olarak dört ana şekilde sinıflandırılabilir (Taylor, 2009). Bunlardan ekonomik ve askeri güç, literatürde genelde sert güç araçları olarak belirtilir. Devletlerarası ilişkilerde belirli bir amaca ulaşmak için sert güç kullanımının çok yaygın olduğu görülmektedir. Güvenlikle ilgili problemlerin çözümünde de öncelikle ana strateji olarak tüm dünya ülkeleri tarafından uzun süre sert güç kullanılmıştır. Tarihsel olarak sert güç, askeri güce, ekonomik güce, doğal kaynaklara, nüfus ve bölgenin büyüklügüne ve toplumsal istikrara dayanmaktadır (Nye, 2004: 3; Nye ve Armitage, 2007: 6). Yani sert güç, devletlerin sahip oldukları askeri ve ekonomik güç unsurlarını diğer aktörleri zorlama, tehdit etme ve caydırma gibi amaçlarla kullanması olarak ifade edilmektedir. Güvenlik bağlamında bir devlet ne kadar sert güce sahipse yani bir ülkenin ekonomik, teknolojik ve askeri gücü ne kadar fazla ise o ülkenin o kadar güvenli olacağı düşünülmüştür. Baldwin (2012: 15) askeri gücün öneminin daha önce çok abartıldığını fakat askeri olmayan güç çeşitlerinin rolünün ise hafife alındığını savunmaktadır. 
Bununla birlikte, terörle mücadelede sadece sert güç kullanımının sorunu çözmekte yetersiz (Nye ve Armitage, 2007) olduğu ABD'de yaygın bir kanı haline gelmiştir. Türkiye de güvenlik problemlerinin çözümünde sert güç stratejisini denemiş ve istenilen amaca ulaşmada sadece sert güç kullanımının yeterli olmadığı görülmüş̧ür. Türkiye'nin uzun yıllardır devam eden terörle mücadelesi buna örnektir. Buna paralel olarak son yıllarda "uluslararası sistemde güç algısının değişmesi, sert güç kullanımının gücü kullanan aktöre meşruiyet sorunları yaratması ve sert gücün maliyetinin yüksek olması aktörleri yeni bir güç arayışına yöneltmiştir" (Tavukçuoğlu, 2013: 70). Bunun sonucunda ülkeler, güvenlik problemlerinin çözümünde alternatif bir yaklaşım olarak yumuşak gücü denemeye karar vermişlerdir. Özellikle teröre karşı savaşın sürdürüldüğü coğrafyalarda yaşayan insanların hem akıllarını çelebilmek hem de gönüllerini kazanabilmek gereklidir. Bunun için de kullanılması gereken tüm stratejik araçlar kamu diplomasisi kapsamında yer almaktadır (Nye 2008).

\section{Yumuşak Güç}

Gücün, gücü kullanan aktöre meşruiyet sorunları oluşturmadan ve sert gücün neden olduğu zafiyetleri yaratmadan aktörlerin amaca ulaşmalarını sağlayabilecek güç türü, yumuşak güç olarak adlandırılmaktadır. Kaynağı ülkenin kültürüne, siyasi değerlerine ve dış politikalarına dayanan yumuşak güç, pek çok ülke tarafından farklı vesilelerle kullanılmaktadır. Özetle yumuşak güç, kuvvet, zorlama ve şiddet kullanmadan başkalarının tercihlerini şekillendirme becerisidir (Payam, 2016). Nye'e göre yumuşak güç, "istenilen şeyin baskı ve herhangi bir ödeme yerine çekici ve cazip hale getirilerek elde edilmesidir" (Nye, 2005: 6). Bir ülkenin yumuşak gücü başlıca üç kaynaktan oluşmaktadır: ülkenin kendi kültürü (bu kültür diğerlerine cazip gelmesi durumunda), ülkenin siyasi değerleri (ülke bu değerlere yurtiçinde ve yurtdışında sadık kalıp yaşarsa) ve ülkenin dış politikaları (ahlaki otoriteye sahip ve meşru olarak görülürlerse - başkalarının bu politikaları meşru görmeleri şartıyla (Nye, 2004). Diğer yandan McClory (2011) ülkelerin yumuşak güç bileşenlerini beş kategoriye ayırır: Hükümet (ülkenin siyasi değerleri), Kültür (toplum için bir mana ifade eden uygulamalar dizisi), Diplomasi (dış politika), Eğitim ve İşletme/İnovasyon.

Nye'ye (2006) göre yumuşak güçte cazip hale getirmek ve birlikte hareket etmek varken sert güçte ise tehdit vardır. Yumuşak gücün kaynağı iletişim iken, sert gücün kaynağı korkutma, gözdağı verme, ödeme ve ödüldür. Yumuşak güç, karizma ve ikna etme yeteneğine önem verirken, sert güçte kiralama, ödeme, terfi gibi yaptırımlar önem kazanır. Yumuşak gücün en önemli unsuru kamu diplomasisidir. Kamu diplomasisinin klasik tanımı yani "bir hükümetin başka bir ulusun halkını ve aydınlarını, bu ulusun politikalarını kendi avantajına olacak şekilde döndürmek amacıyla etkilemeye çalışması" aynı zamanda alg1 yönetimi kavramının tanımını çağrıştırmaktadır.

McClory (2011: 24) "sadece yumuşak gücün yeterli olmayabileceğini fakat sert güçle kıyaslandığında yumuşak gücün göreceli stratejik öneminin artmaya devam edeceğini" iddia etmektedir. Güvenlik problemlerinin çözümünde sadece yumuşak güç kullanımının bir noktaya kadar etkili olduğu görülmüş fakat istenen netice elde edilememiştir. Sadece yumuşak güç kullanımının güvenliği sağlamada ve terörle mücadelede yeterli olmadığının kanıtlarını örneğin Türkiye'nin çözüm sürecinde görmek mümkündür. Nye'e (2006) göre de yumuşak veya sert güç artık tek başına 
yeterli değildir. İçinde yaşadığımız bilgi çağında, durum ve şartlara göre sert ve yumuşak gücün birlikte kullanılması yani akı1lı gücün kullanılması gerekir. Wilson'a (2008) göre akıllı güç, hedef kitlenin imkân kabiliyetini bilerek yumuşak güç ve sert gücün ne zaman, nerede, hangi seviyelerde ve nasıl kullanılacağını bilmektir.

\section{Akıllı Güç}

Sert ve yumuşak gücün olumsuz yönlerini elimine edip olumlu yönlerini kendi içerisinde birleştirerek "akıllı güç" adında yeni bir yaklaşım ortaya konmuştur. Ak1llı güç, dayatma ve ödetmeye odaklı "sert güç" ile ikna etme ve cezbetmeye dayalı "yumuşak gücün" bir birleşimidir (Nye, 2008). Akıllı güç, "diplomatik iknanın stratejik kullanımını, kapasite geliştirmeyi ve ekonomik ve etkili bir şekilde siyasi ve sosyal meşruiyete sahip olacak şekilde güç ve etki projeksiyonunu içerir (Nye ve Armitage, 2007). Aslında akıllı güç, diplomatik, ekonomik, askeri, politik, yasal ve kültürel araçların bir birleşimidir (Pallaver, 2011). Kısaca akıllı güç, sert ve yumuşak gücün alg1 yönetimi de kullanılarak hünerli bir şekilde birleştirilmesidir. İstenilen sonucu elde etmede askeri ve ekonomik güç gereklidir ama uzun vadede kendi çıkarlarınız açısından yetersizdir. Kendi nüfuzunuzu yaymak, başkalarına haklı olarak müdahale etmek ve kullandığınız güce meşruiyet kazandırmak için çeşitli ittifaklar, ortaklıklar ve etkin kamu diplomasisine gereksinim vardır. Akıllı güce artan ilgi, biri yapısal ve uzun vadeli, diğeri ise şu andaki yönetimin politikaları tarafından yönlendirilen kısa vadeli ve konjonktürel olmak üzere iki çağdaş eğilimi yansıtır (Wilson, 2008). Özetle, akıllı güç sadece yumuşak güç olmayıp, sert ve yumuşak güç unsurlarının değişik şartlara, zamana, yere ve konjonktüre göre etkin bir biçimde birleştirilerek kullanılmasını öngörür.

Bununla birlikte diğer önemli olan husus, tüm bu araçları yani akıllı gücü kullanırken algıları da değiştiriyor ve yönetebiliyor olmanızdır. Sert veya yumuşak güç kullanımları bakımından algı yönetimi, soğuk savaş döneminden beri bazı devletler tarafindan bir araç olarak kullanılmıştır. Günümüzde dahi toplumsal güvenliği sağlamada sadece sert güç veya sadece yumuşak güç kullanımının sorunu çözmekte yetersiz olduğu görülmektedir. Dolayısıyla akıllıca yürütülecek bir güvenlik politikası, askeri ve ekonomik gücün yanı sıra yumuşak güç, akıllı güç ve alg1 yönetimi çalışmalarını da kapsamalıdır. Bu gerçek başta ABD olmak üzere tüm batılı ülkelerce kabul edilmiş ve batılı ülkeler özellikle de ABD yıpranan imajının yeniden düzelmesi için yoğun bir algı yönetimi kampanyasına başlamıştır. Wilson'a (2008) göre, akıllı güce ulaşmak ve etkin şekilde kullanmak, kavramsal, kurumsal ve politik unsurları, dış politika yeniliklerini geleceğe taşıabilecek bir reform hareketine ustaca birleştirmeyi gerektirir. Yani, akıllı gücün akıllı bir kampanyaya ihtiyacı vardır. Bu açıdan algı yönetimi kavramının bir çeşit akıllı güç olarak kullanıldığını ve hedefinin kalpleri kazanmak, gönülleri ve zihinleri fethetmek olduğunu söyleyebiliriz.

\section{Algı(lama) Yönetimi}

Küreselleşen dünyada gündemi belirlemek ve yönetmek ve kamuoyunu etkilemek için kullanılan araçlardan birisi algıları yönetmektir. Alg1 yönetimi kavramı, "stratejik iletişim", "bilgi savaşları", "propaganda" ve "psikolojik operasyonlar" gibi kavramlar ile birlikte düşünülmekte ve bu kavramların içeriği birbirini tamamlamaktadır (Hügül, 2011). Alg1 yönetimi, ikna, propaganda, manipülasyon,

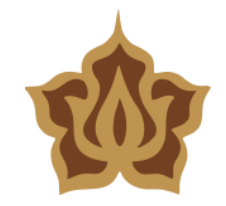


kamu diplomasisi, stratejik iletişim gibi ikna ve iletişim becerileriyle ilişkili bir süreçtir (Gültekin, 2016:). Yukarıda sayılan kavramlar, kamuoyunda olumsuz çağrışımlar yaptığı için kulağa daha hoş gelen "kamu diplomasisi" ve "alg1 yönetimi” gibi kavramlar günümüzde tercih edilmektedir (Öksüz, 2013). Devletlerin kendi çıkarları için uluslararası düzlemde algı yönetimini kullanmaları ise genelde "kamu diplomasisi" olarak adlandırılmaktadır (Tunç ve Atılgan, 2017). Kısaca kamu diplomasisi, "bir devletin, hedef devletin politikalarını kendi çıkarları doğrultusunda değiştirmek amacıyla, hedef devletin halkını ve aydınlarını etkileme çabasıdır" (Potter, 2002: 3). Kamu diplomasisinin bu tanımı dahi, alg1 yönetiminin tanımına benzeyip, dolaylı olarak algı yönetimi kavramına işaret etmektedir.

Güncel Türkçe sözlükte alg1, "bir şeye dikkati yönelterek o şeyin bilincine varma, idrak" (TDK, 2018) olarak tanımlanır. Bazı yazarlar tarafından bilgi savaşı olarak da adlandırılan "alg1 yönetimi" ise, hedef insan veya toplumu hedef alanın istediği şekilde düşünmeye ikna etmek için etkilemesidir. Yani, "ikna ve inandırma faaliyetleri”, alg1 yönetiminin özünü oluşturmaktadır (Öksüz, 2013). Saydam (2005) algılama yönetimini "iletişimin beyni, atar damarı, uzuvları, yani her şeyi" olarak tanımlar. Özer'e (2012) göre algı yönetimi, veri ve bilgi akışını sağlamak için kullanılan bir yönetim tekniğidir. Alg1 yönetimi, "hedef insan veya toplumu, hedef alanın istediği şekilde düşünmeye ikna etmek için etkilemesidir" (Özdağ, 2015). İlk kez ABD Savunma Bakanlığı tarafindan kullanılan alg1 yönetimi, "yabanciların her seviyedeki istihbarat birimleri ve liderleri de dâhil olmak üzere, bu ülkelerdeki geniş kitlelerin kendi hedefleri doğrultusunda tavır almaları ve resmi adımlar atmalarını sağlamak amacıyla, seçilmiş bilgi akışını ve somut belgeleri yönlendirerek ya da reddedilmesini sağlayarak, kitlelerin hislerini, güdülerini, düşünce sistemlerini etki altına almaya çalışmak için yürütülen eylemlerin tamamını kapsar. Alg1 yönetimi, çeşitli yolları kullanarak gerçekleri yansıtma, operasyon güvenliği, gizleme ve çarpıtma, psikolojik operasyonları yönetme gibi unsurları birleştirir" (DoD Dictionary, 2001: 411; Hügül, 2011; Öksüz, 2013; Özer, 2012; Saydam, 2005; Saydam, 2007)

Yani alg1 yönetimi, diğer insanların ABD hedefleri doğrultusunda tavır almaları ve resmi adımlar atmalarını sağlamak amacıyla, seçilmiş bilgi akışını ve somut belgeleri yönlendirerek ya da reddiyesini oluşturarak, kitlelerin hislerini, güdülemelerini, düşünce sistemlerini etki altına almaya çalışmak için yürütülen eylemlerin tamamıdır. Saydam'a (2007) göre "algı yönetimi, ABD menşeli bir kavram olarak, Amerikan siyasi kararlarının ülkede ve tüm dünyada benimsenmesi amacıyla kullanılan bir yöntem olarak ortaya çıkmaktadır" (Saydam, 2007: 28). Özer (2012)'e göre de algı yönetimi, gerek ülke içinde gerekse yabancı ülkelerdeki hedef kitlelerin görüşlerini etkilemek için yapılan faaliyetlerin tamamını kapsamaktadır.

Özetle alg1 yönetimi, geniş anlamıyla bilginin veya gerçeklerin nasıl algılandığının veya nasıl algılatılacağının kontrolüdür. Bu kapsamda bilginin veya gerçeklerin belirli çıkarlar uğruna manipüle edilip hedef kitleyi yönlendirmek amacıyla kullanılmasında alg1 yönetimi stratejileri önemli bir paya sahiptir (Öksüz, 2013). İnsanın en sert ve en güçlü organı olan beyninin, yine alg1 yönetimi vasıtasıyla çeşitli güçler kullanılarak yönlendirilmesi çok manidardır. Siegel'e (2005) göre algı yönetiminin üç amacı vardır: 
1. Meşruiyet kazanmak ve sürdürmek için yurtiçinde ve yurtdışında kamuoyu desteği oluşturmak ve korumak,

2. Eylemlerinin sonuçlarını tam olarak anlamaları için muhaliflere ve/veya üçüncü taraflara yüksek derecede güvenilirlik kurmak amacıyla niyet ve hedefleri iletmek,

3. Yerel halkların, alg1 yönetimini uygulayanın hedeflerine uygun olarak hareket etmeleri için tutumlarını ve davranışlarını etkilemek (Siegel, 2005: 118-119).

\section{Güvenlik, Güç Kullanımı ve Algı Yönetimi}

Devletlerin kendi çıkarlarını korumak, bölgesel ve küresel bir güç olmak ve vatandaşlarının güvenliğini sağlamak için çeşitli düzeyde güç kullanmak durumunda kaldıklarından bahsedilmişti. Güvenliği sağlama noktasında yukarıda belirtilen herhangi bir güç kullanımının kararı ise, birçok farklı etkenin çok dikkatli bir şekilde değerlendirilmesini zorunlu k1lar. Pallaver (2011) karar verme süreci ve güç seçimini dört adımda rasyonelleştirmektedir: bağlamı (durum ve şartları) anlama, uygun güç seçimi, istenen sonuçlar için çare olarak gücün etkililiği ve gündemin başarılı bir şekilde uygulanması. Yukarıda sayılan güç unsurlarının hepsi aslında hedef toplumun/devletin, zorunlu veya kendi isteğiyle, kendi planladığımız hedefler doğrultusunda, ikna edilmesini veya algısının değiştirilmesini kapsamaktadır (Hügül, 2011).

Alg1 yönetimi ile geçerlilik kazanmak ve korumak için kamuoyu desteği oluşturmak ve korumak ve belirlenen topluluğun davranış ve tutumlarını istenilen doğrultuda etkilemek amaçlanmaktadır (Bakan ve Kefe, 2012). Algı yönetimi, askeri faaliyetlerin merkezinde yer alan bir unsur olarak hem orduların hem de teröristlerin sıklıkla başvurduğu bir araç haline gelmektedir (Siegel, 2005). Alg1 yönetiminin askerî operasyonlar için kilit bir rolü vardır. Yani alg1 yönetimi, askeri başarı için bir anahtardır (Siegel, 2005; Zaman, 2007). Günümüzde değişen güvenlik anlayışı insan hayatına ve kişisel hak ve hürriyetlere verebileceği zarar ve fayda açısından el alındığından devletlerin güvenlik politikalarını inşa ederken askeri gücün yanı sıra yumuşak güce, dolayısıyla kamu diplomasisi araçlarını dikkate almaları hususunu ön plana çıkarmıştır (Coşkun, 2012). Yukarıda sayılan bütün güçler, gücün herhangi bir türü gibi iyi ve kötü amaçlarla kullanılabilir. Güvenlik bağlamında algı yönetimi, uygulanan güvenlik uygulamalarının ulusal ve uluslararası kamuoyunda benimsenmesi ve kabul görmesini sağlamak amacıyla kullanılmaktadır. Devletler; diğer devletlerin üzerinde etki kurma, uluslararası alanda bir imaj oluşturma ve ülke çıkarlarına yönelik hedef ülke halklarını çıkarları doğrultusunda yönlendirme açısından alg1 yönetimini uygulamaktadır (Tunç ve Atılgan, 2017).

Henry Kissinger'ın 'Bir şeyin gerçek olması pek o kadar önemli değildir; ancak gerçek olarak algılanması çok önemlidir" sözü algı yönetiminin günümüzde ne kadar önemli olduğuna işaret etmektedir. Yani alg1 yönetimiyle, hedef kitlede oluşan gerçek, gerçeğin kendisinden daha önemli hale gelmektedir. Bu bağlamda, güvenliği sağlamak adına güç kullanımı ancak haklı bir gerekçeye dayandırıldığ 1 sürece meşrudur. Fakat haklı bir gerekçeye dayanmayan güç kullanımı, alg1 yönetimi ile meşru gibi gösterilebilmektedir. Bu bağlamda, çeşitli düzeyde güç kullanan devletlerin en etkin ve sessiz silahı algıları yönetmektir denilebilir. 
Günümüzde alg1 yönetiminde kullanılan araçlar farklılaşarak artmış ve teknoloji özellikle de sosyal medya daha fazla kullanılmaya başlanmıştır. Kitle iletişim araçları vasıtasıyla algıların yönetilmesinde temel amaç, devletlerin iktidarlarının ve politikalarının meşruiyetini sağlamak, güvenliği sağlamaya yönelik kullanılacak veya kullanılan güç yönteminin meşru olduğuna halkı inandırmak, sert veya yumuşak güç kullanmanın kamu vicdanında kabul görmesi, güç kullanımı konusunda hali hazırda var olan desteği arttırmak, kitlelerin sahip oldukları güvenlik algılarını değiştirmek ya da insanların istenilen düşünce ve duyguları benimsemesini sağlamaktır. Bu açıdan alg1 yönetimi, "güvenlik" tehditlerinden ötürü haklı olarak güç kullanıldığına halkı inandırmak ve kullanılan gücü meşrulaştırmaktır.

Alg1 yönetiminin kimilerine göre olumlu, kimilerine göre ise olumsuz bir kavram olarak değerlendirildiği görülmektedir. Diğer bir anlatımla, alg1 yönetimi algıları ile oynananlar açısından olumsuz, algıyı yönetenler açısından ise olumlu sonuçlar veren bir süreçtir. Algı yönetimi, yanlış bir algıyı düzeltmek için kullanılabileceği gibi, genelde Batının yaptığı gibi insanları kandırmak, gerçekleri gizlemek ve çarpıtmak ve asıl niyeti gizlemek gibi amaçlarla da kullanılabilir. Bununla birlikte, ulusal ve uluslararası güvenlik bağlamında, ahlaki ve hukuki sınırlar dâhilinde doğru ve etkin bir alg1 yönetimi sürecinde aşağıdaki temel kurallara uygun hareket edilmelidir (Saydam, 2007):

1. Hedef kitlenin değerlerine uyum sağlamalı,

2. Hedef kitlenin kültürüne özen gösterilmeli,

3. Beklentilerin üzerinde yaklaşım sergilenmeli,

4. Kafalar karıştırılmamalı, yalın ve anlaşılır olmalı,

5. Sonuca odaklanılmalı,

6. Ölçülemiyorsa yapılmamalı,

7. Gerçeklere dayanmalıdır,

8. Tekrar edilmeli,

9. Farklılaşmalar yönetilebilmeli,

10.Görsellik doğru yönetilmeli

11.Düşüncelerden çok duygulara hitap edilmelidir.

Bu ilkelerden "gerçeklere dayanmalıdır" ilkesiyle kastedilen yalan söylemek değil, her doğrunun söylenmemesi gerektiğidir. Diğer bir ifadeyle, "Senin üzerine haktır ki, her söylediğin hak olsun. Fakat her hakkı söylemeye senin hakkın yoktur. Her dediğin doğru olmalı; fakat her doğruyu demek doğru değildir”.

\section{Sonuç}

Sonuç olarak, insanlarda oluşan veya oluşturulan tehdit algıları, güvenlik stratejilerinin geliştirilmesinde önemli rol oynamakta ve çeşitli düzeyde güç kullanımını gerekli kılmaktadır. Fakat çeşitli düzeyde güç kullanımının, gücü kullanan aktöre meşruiyet sorunları oluşturması, güç kullanımı ve algı yönetimi ilişkisini gündeme getirmiştir. Bu durum, sert güç kullanımının yanı sıra yumuşak güç ve akıllı güç kullanımına da önem verilmesi ve etkin bir alg1 yönetimi çalışmasını gerektirmektedir. Kişiler, devletler veya her kim tarafindan hangi çeşit ve düzeyde ve hangi amaçla kullanılırsa kullanılsın, güç ancak haklı bir gerekçeye dayandırılarak kullanılmalıdır. "Kuvvet haktadır; hak kuvvette değildir" ilkesi gereği, güçlünün haklı olduğu değil, haklının güçlü olduğu bir dünya inşa etmek 
durumundayız. Türkiye, herhalde ahlaki sınırlar dâhilinde algı yönetimini etkin bir şekilde kullanarak akıllı güç odaklı küresel bir güvenlik sağlayıcı güç haline gelmelidir ve gelecektir. Bunun için kendi menfaatlerimiz ve tüm insanlığın menfaatleri doğrultusunda ulusal bilince sahip, bilgi üreten ve bilgiyi yöneten eğitimli ve donanımlı insanlar yetiştirmek durumundayız.

Milli güvenliğimizi ilgilendiren algı yönetimi çalışmaları, hükümet politikası olarak değil devlet politikası olarak tüm teknolojik imkân ve araçlar kullanılarak uygulanmalıdır. Fakat Türkiye her halükarda, genelde tüm insanların, özelde ise kendi vatandaşlarının ve devletinin güvenliğini sağlamada demokratik, etik ve insani değerler çerçevesinde sert ve yumuşak gücünü ahlaki alg1 yönetimiyle birlikte planlı ve tutarlı bir şekilde kullanmalıdır. Bu bağlamda, diğer aktörlerden farklı olarak güvenliği sağlama noktasında Türkiye'nin kendine has kullandığı güç "adil güç" olarak tanımlanabilir. Son olarak, günümüzde siber güvenlik tehditleri de göz önüne alındığında Türkiye'nin sahip olacağı "siber güç", uluslararası sistemde gücün el değiştirmesinde etkili olacaktır. Çünkü siber alanlara girmek sadece bir tık ötemizdedir ve bu alanlarda sert, yumuşak ve akıllı güç algı yönetimiyle birlikte çok etkin bir şekilde kullanılmaktadır...

\section{Kaynakça}

Akay, Emrah (2014). "Kapitalizmin Son Oyunu; Alg1 Yönetimi”, Köklü Değişim Dergisi, 11, Haziran 117, s. 29-34.

Arı, Tayyar (1997). Uluslararası İlişkiler, 2. Baskı, ALFA Yayınları, İstanbul.

Bakan, İsmail; Kefe, İlker (2012). "Kurumsal Açıdan Algı ve Algı Yönetimi”, KSÜ IIBF Dergisi, Sayı:1 Cilt: 2, s. 19-34.

Baldwin, David A (2012). "Power and International Relations", in Handbook of International Relations. http://www.princeton.edu/ dbaldwin/selecte\%20 articles/Baldwin\%20(2012)\%20Power\%20and\%20International\%20Relati ons.pdf.

Çoşkun, Beren (2012). "Güvenlik Sorunları ve Kamu Diplomasisi”, Кати Diplomasisi, (Editör: A. Özkan, T. E. Öztürk), Tasam Yayınları, İstanbul.

Department of Defense Dictionary of Military and Associated Terms (2001). Joint Publication 1-02. ABD Savunma Bakanlığı. Erişim: 27 Temmuz 2017, https://marineparents.com/downloads/dod-terms.pdf.

Gültekin, M. (2016). Algı Yönetimi ve Manipülasyon, Pınar Yayınları, İstanbul.

Hügül, Hakan (2011). Algı Yönetimi ve Medya: Inegöl Olaylarının Basında Sunuluşunun Algl yönetimi Kapsamında Analiz Edilmesi, Kara Harp Okulu, Savunma Bilimleri Enstitüsü Güvenlik Bilimleri Ana Bilim Dalı, Yayınlanmış Yüksek Lisans Tezi, Ankara

McClory, Jonathan (2011). "The New Persuaders II. A 2011 Global Ranking of Soft Power", Institute for Government. https://www.instituteforgovernment.org.uk/sites/default/files/publications/ The $\% 20$ New\%20PersuadersII_0.pdf

Nye, Joseph S (2004). Soft Power: The Means to Success in World Politics, Public Affairs, New York.

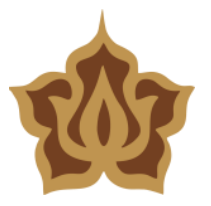


Nye, Joseph S (2005). Yumuşak Güç: Dünya Siyasetinde Başarının Yolu, Elips Kitap, Ankara.

Nye, Joseph S (2006). "Hard Power, Soft Power and Leadership", Seminer, 2006. <http://www.hks.harvard.edu/netgov/files/talks/docs/11_06_06_seminar_N yeHP_SP_Leadership.pdf>, 12.01.2011.

Nye, Joseph S (2008). "Public Diplomacy and Soft Power", The ANNALS of the American Academy of Political and Social Science, 616(94).

Nye, Joseph S (2011). The Future of Power, Public Affair, New York.

Nye, Joseph S; Armitage, Richard L (2007). CSIS Commission on Smart Power: A smarter, more secure America, Center for Strategic and International Studies, Washington.

Öksüz, Harun (2013). "Alg1 Yönetimi ve Sosyal Medya”, İdarecinin Sesi Dergisi, May1s-Haziran s.12-15.

Özdağ, Ümit (2015), Algı Yönetimi, Propaganda, Psikolojik Savaş, Kripto Basım Yayım, Ankara.

Özer, M. Akif (2012). "Bir Modern Yönetim Tekniği Olarak Algılama Yönetimi ve İç Güvenlik Hizmetleri”, Karadeniz Araştırmaları Dergisi, Sayı:33, s. 147 180.

Pallaver, Matteo (2011). Power and its Forms: Hard, Soft, Smart. Department of International Relations, London School of Economics. Unpublished Master Thesis, London.

Payam, M. Murat (2016). "The Role of "Positive Action" in Countering Terrorism", International Journal of Development Research, 6(10), 98769881.

Potter, Evan H (2002). "Canada and the New Public Diplomacy", Netherland Institute of International Relations, 58(1).

Saydam, Ali (2005). Algılama Yönetimi, Rota Yayınları, İstanbul.

Saydam, Ali (2007). Illetişimin Akıl ve Gönül Penceresi Algllama Yönetimi. Rota Yayınları, İstanbul.

Siegel, P. Combelles (2005). "Perception Management: Io's Stepchild", Low Intensity Conflict and Law Enforcement, 13 (2), pp.117-134.

Tavukçuoğlu, Cengiz (2013). "Sert Gücün Yumuşak Güce Dönüşmesinde Algılama Yönetimi", Algılama Yönetimi, (Editör: A. Yalçınkaya), Bahçeşehir Üniversitesi Yayınları, İstanbul, s. 69-84.

TDK (Türk Dil Kurumu), http://www.tdk.gov.tr/, 2018.

Tunç, Ahmet; Atılgan, Ali (2017). "Algı Üzerine Kurulu Yönetsel Bir Anlayış: Algı'nın Yönetimi”, International Journal of Disciplines Economics \& Administrative Sciences Studies, Vol:3 Issue:3 pp:228-238. 
Varoğlu, M. Abdülkadir (2013). "Algılama Yönetiminin Anlamsal Değişimi ve Kültürel Boyutları", Algılama Yönetimi, (Editör: A. Yalçınkaya), Bahçeşehir Üniversitesi Yayınları, İstanbul, s. 1-20.

Wilson, Ernest J (2008). "Hard Power, Soft Power, Smart Power". The ANNALS of the American Academy of Political and Social Science, 616.

Zaman, Khyber (2007). Perception Management: A Core Iq Capability, Master Of Science In Information Warfare Systems Engineering And Master Of Science In Information Operations, Naval Postgraduate School, Monterey, California. 